\title{
Thaksin Overthrown: Thailand's "Well-Intentioned" Coup of September 19, $2006^{1}$
}

\section{Michael H. Nelson ${ }^{2}$}

Thaksin Shinawatra's Thai Rak Thai (TRT - Thais Love Thai) Party was registered on July 14, 1998. In the general elections of January 4, 2001, it won 248 out of the 500 seats in the House of Representatives. Four years later, this number had increased to 377 seats. Thaksin's power seemed to be unassailable for the next four, eight, or even twelve years. Thai Rak Thai's slogan for its second term in office was an optimistic policy promise: si pi som si pi sang (four years of repairs, four years of construction). Everything looked as if Thaksin would "become Thailand's greatest leader of modern times" (Thanong Khanthong in The Nation, Oct. 2 , 2006). Instead, only twenty months after this electoral euphoria, while Thaksin was in New York to give a speech at the United Nations, Thailand's military rolled out its tanks, surrounded Government House and secured strategic positions throughout Bangkok. Thaksin's desperate attempt to declare a state of emergency on television was cut short. On the night of September 19, 2006, Thailand's supposedly "greatest leader" was turned into a "tyrant in exile," thus producing the most astonishing political meltdown in recent Thai political history. By October 3, 2006, important faction leaders and their followers had left TRT. On the same day, in a handwritten letter faxed from his exile in London, Thaksin declared his resignation from the position of TRT chairman.

\footnotetext{
1 This title is a reference to the coup group's joint televised address on September 20, 2006. Its concluding sentence reads, "The Council therefore requests cooperation from all fellow citizens to remain calm and to support this undertaking so that it achieves its well-intentioned objectives" (quoted according to the unofficial translation to be found at http://www.mfa.go.th/web/2473.php.

2 This text is the pre-print version of a chapter that will appear in a book on Thai politics, edited by Thang D. Nguyen. The manuscript was finished on October 26, 2006.
} 


\section{Thaksin's decline}

That Thailand would lose its overbearing political leader in a military putsch could not be anticipated when-in retrospect-the process was set in motion. ${ }^{3}$ On September 16, 2005, Sonthi Limthongkul lost his weekly political talk show, Muang Thai Rai Sapda (Thailand Weekly), that had been aired live on TV Channel 9 since July 2003. While Sonthi, the founder of Manager newspaper, had earlier supported Thaksin, he later used his show to relentlessly attack Thaksin and his government. Channel 9's decision was thus seen as an attempt by Thaksin to silence one of his most vocal critics. Sonthi, however, opted for going public. He first performed his show at Thammasat University, and then moved to Lumpini Park to accommodate tens of thousands of listeners. By January 2006, Sonthi's crusade seemed to falter. A mass demonstration at Sanam Luang, scheduled for February 4, was generally seen as a good opportunity for him to leave the scene in a "soft landing" (Bangkok Post, Jan. 22, 2006). It was Thaksin himself who fatally turned the situation around to his own disadvantage by selling his Shin Corporation to Temasek, the Singaporean government's investment company. The sale was announced on January 6 and almost immediately inflamed the public, especially because the sale had been executed in such a way that the Shinawatra family did not have to pay a single baht of tax on proceeds totaling 73 billion baht.

On February 6, Sonthi and some well-known democracy activists established the People's Alliance of Democracy (PAD). However, the PAD gained its real strength only when Buddhist sectarian Chamlong Srimuang-a former Bangkok governor and chairperson of the Palang Dharma Party (PDP), who had made Thaksin his successor at PDP-and his "Dharma Army" (Chamlong is a former army major-general) of disciplined followers joined the PAD. ${ }^{4}$ Chamlong had galvanized the protests leading to Prime Minister Suchinda Kraprayoon's downfall in May 1992, and he now declared that he would carry on with his protests until Thaksin resigned. ${ }^{5}$ The Nation (Feb. 20, 2006) saw Chamlong's decision as "one of the severest blows" to the prime minister, and a "major boost" for the PAD. Only five days later, and two days before the next big planned demonstration, Thaksin dissolved parliament on

\footnotetext{
${ }^{3}$ What follows is a very brief description. For more details see Kasian (2006), Murphy (2006), and Nelson (2005; 2006a).

4

One of his reasons was that his former boss, Prem Tinsulanonda (see the text below), had been attacked by two right-wing TV commentators. Later, Thaksin asked Prem whether he had in fact supported Chamlong in joining PAD. Prem denied this.

5 Thaksin is Chamlong's third prime ministerial trophy, since he also played a part in toppling the Seni Pramoj government in October 1976. At that time, soldier Chamlong was among the right-wing instigators (McCargo 1997: 33ff.; Thongchai 2002: 255f.).
} 
February 24, and called fresh elections for April 2, 2006. On March 14, PAD "troops," mainly Chamlong's "army," started beleaguering Government House, in conjunction with evening mass demonstrations by tens of thousands of members of the Bangkok middle class (millions stayed at home, though).

The election of April 2, 2006, turned into a farce because all parliamentary opposition parties-the Democrats, Chart Thai, and Mahachon-boycotted the polls. This meant that many TRT candidates had no competitors in many of the 400 constituencies. In such cases, a candidate only wins the seat if he or she is supported by at least 20 percent of the eligible voters. As a result, dozens of seats remained unfilled after the first round of voting. The second round also failed to produce the full complement of 400 MPs, and there was-mainly in the Democrat strongholds in the south-no prospect of ever filling the remaining seats. Therefore, the House could not convene within the legally stipulated 30 days after election day, because this requires the presence of all 400 members.

In this situation, on April 25, the King intervened in an unusually direct and strong manner. He took the occasion of two separate audiences for judges of the Supreme Court and the Supreme Administrative Court to ask whether the problems were so severe that only a nullification of the election could solve them. He strongly reminded the judges of their legal duties:

Should the election be nullified? You have the right to say what's appropriate or not. If it's not appropriate, it is not to say the government is not good. But as far as I'm concerned, a one party election is not normal. The one candidate situation is undemocratic. When an election is not democratic, you should look carefully into the administrative issues. I ask you to do the best you can. If you cannot do it, then it should be you who resign, not the government, for failing to do your duty. Carefully review the vows you have made. . . The nation cannot survive if the situation runs contrary to the law. Therefore, I ask you to carefully study whether you can make a point on this issue. If not, you had better resign. You have been tasked with this duty. You are knowledgeable. You must make the country function correctly. ${ }^{6}$

The King also denounced the PAD's persistent calls to replace the Thaksin government with a royally appointed government, based on Article 7 of the Constitution:

I have suffered a lot. Whatever happens, people call for a Royally appointed prime minister, which would not be

\footnotetext{
${ }^{6}$ Quoted according to an unofficial translation in The Nation (April 26, 2006). The King's speeches were printed in all major Thai-language newspapers.
} 
democracy. If you cite Article 7 of the Constitution, it is an incorrect citation. You cannot cite it. Article 7 has two lines: whatever is not stated by the Constitution should follow traditional practices. But asking for a Royally appointed prime minister is undemocratic. It is, pardon me, a mess. It is irrational. . . . People call to "rescue the nation." Whatever they do, they call [it] "rescue the country." What do you rescue? The country has not sunk yet. We have to prevent it from sinking, we do not have to rescue it. (The Nation, April 26, 2006)

It took the Constitutional Court only until May 8, 2006, to follow His Majesty's suggestion and annul the April election. On July 25, 2006, the Criminal Court sentenced the remaining three members (of the five, one had died in office and another had resigned) of the Election Commission of Thailand (ECT) to unsuspended four-year prison terms for malfeasance in office while organizing the April election, and the King later signed an amended royal decree stipulating that new elections were to be held on October 15. In an unprecedented gesture, the King unequivocally expressed his political will in a handwritten phratchakrasae (royal message) to Prime Minister Thaksin, attached to the royal decree. In this message, the King said that he had signed the amended decree because he wanted the nation swiftly to return to peace and order. Moreover, he wanted the election to proceed in a truly orderly, clean and fair manner (Matichon, July 23, 2006: 13). Finally, in keeping with the King's guidelines to have the judiciary solve the political "mess," the Senate, on September 8, 2006, selected four senior judges and one deputy attorney-general as the new election commissioners.

Everything seemed to proceed within the frame of reference suggested by the King. A small obstacle was that the election date would have to be postponed by one or two months, in order to give the new ECT members time to familiarize themselves with their new tasks. The political parties already had entered into campaign mode. One big obstacle, though, could not be overcome: Thaksin Shinawatra, typically so proud of his fast thinking and decisionmaking, endlessly hesitated to announce whether or not he would temporarily withdraw from politics. Even important factions within TRT thought that it would be better for Thaksin to make clear that he would not accept the position of prime minister after the election. Maybe Thanong Khanthong was right when he headlined his comment quoted above "Thaksin gambled and lost his shirt" (The Nation, Oct. 2, 2006). Maybe Thaksin's great pride and ego prevented him from making a politically sensible decision. Or maybe Thaksin did not realize that this was a situation he earlier had described in the following words: 
I'm the Ghengis Khan type of manager. When you start a company, you need someone to propel it, to set a vision and force everyone to work like barbarians. But after a certain point you need a builder, who must be professional, so they don't need someone like me any more, who might push too hard (quoted in McCargo and Ukrist 2005: 109; originally from The Nation, Jan. 8, 2001).

Whatever the case might be, Chaturon Chaisaeng, who took up the position of interim chairperson of TRT after Thaksin had resigned, thought that Thaksin's hesitation might have been an important reason for the coup. According to Chaturon, he had suggested to Thaksin that he take a break. Although Thaksin had thought about a solution to the crisis, he had been unable to decide when to make a declaration. "Today the impact [of his hesitation to decide] is too great. The medicine [they are using to cure the crisis] is too strong and beyond our thoughts. I'm not sure - if Thaksin had taken a break at that time - how the situation would be now," Chaturon said (The Nation, Oct. 19, 2006).

\section{The coup as a clash of cultures}

Soon after Thaksin had become prime minister following the election of January 6, 2001, he started to antagonize Bangkok's critical public and, more importantly, the capital's monarchist, bureaucratic, and military establishment. Until 1988, the establishment had little problem with that new kid on the block: politicians. Members of the traditional elite did not really understand why such people had to meddle in the affairs of the state so well looked after by the establishment already. But if accepting politicians as part of developing "democracy" was necessary, the elite were prepared to give them a cautious try. When the first "fully elected" government after eight years of "Premocracy" (Yos 1989) went too far in challenging the bureaucracy, and in particular the military, it was promptly deposed in the coup d'état of February 1991. Subsequent weak coalition governments posed little threat to the elite, and only reiterated their conviction that government by elected politicians was a step backward from what had been achieved already. Moreover, politicians represented unwelcome competition for the spoils of office.

With Thaksin, elected government became immensely strong and centralized. Thaksin and his people introduced a worldview about steering the state that had been unheard of before, aptly summarized as the " 'A Country Is My Company' Approach" (Bidhya 2004). The position of prime minister was equated with that of the chief executive officer (CEO) of a company. Already before Thaksin founded TRT, he had expressed part of his political outlook by saying, "A company is a country. A country is a company. They are 
the same. The management is the same. It is management by economics" (quoted in Pasuk and Baker 2004: 101). The CEO must have full control of the company's affairs, unchallenged by rival centers of power, such as the bureaucracy or the military, or even the monarchy. Obviously, things like a free press, competitive politics, a vibrant public, and open criticism of the rulers do not fit into this model either. Thus Thaksin's strong preferences for "quiet politics" (kanmuang ning).

Only a few months after Thaksin had taken office, a core member of Bangkok's establishment fired a warning shot. Liberal royalist Anand Panyarachun, in a speech to commemorate the 25th anniversary of October 6, 1976, said:

Dictatorship no longer comes from the military or those in khaki uniforms. Rather, it depends on a person's mind: to what extent he or she understands democracy; on whether power is sought and used constitutionally or not. Danger caused by people with dictatorial inclinations has not disappeared from Thailand, although there is less intensity perhaps, or the means have changed. Meanwhile, there are new means of suppressing democracy-deceiving means that lull people into satisfaction, that make them slumber for a while, having happiness (Matichon, Oct. 8, 2001:2).

Two months later, the King used his annual birthday speech to strike out against the "egoism" and "double standards" of the Thaksin government. The King made fun of Thaksin, telling the audience that the prime minister was making a "long face" listening to his remarks. The Nation (Dec. 6, 2001: 4A) commented, "No government in recent memory has witnessed such a pessimistic speech from the King, and nobody in the Royal audience must have felt his words more distinctly than Premier Thaksin, who turned increasingly red towards the end."

Four years on, things had gone from bad to worse. The enormously influential former army chief and prime minister, Gen. Prem Tinsulanonda-as president of the King's Privy Council and one of His Majesty's closest confidants-in a speech given at the National Institute of Development Administration, again raised the specter of "double standards." Thaksin was accused of employing one set of standards for himself, his family, and his friends, and another set to people outside his circle. "Prem also warned the government of Prime Minister Thaksin Shinawatra to curb rampant corruption or face being removed from office before its term ended" (The Nation, July 10, 2005). The Bangkok Post (July 12, 2005) headlined its comment "Pride could lead to fall." This perspective was reinforced when the King, in his 2005 birthday speech, pointed to the serious consequences of careless political actions by using words such as "dead" and "die." The King said: 
Had I not been careful enough, I would have been dead. If we do wrong, we will also die. Everybody is in this same situation. Those who hold high rank in society, if they are not careful enough, they will die too ... I am not condemning anyone, but if we are not careful, Thailand will perish. I ask you all to be careful, very careful with what you think, speak, or do. If you think it is right, go ahead and do it (The Nation, Dec. 13, 2005).

That the endgame probably had started could be sensed when, about six months later, Thaksin went on the offensive by delivering a prepared speech to hundreds of high-level civil servants at Government House to claim that a "charismatic person outside the constitution" had been trying to replace him as prime minister. Most observers interpreted this remark as a reference to Prem Tinsulanonda. Thaksin confirmed, "I will not allow any changes that don't observe the democratic process. I will protect democracy. Let me repeat, I will protect democracy with my life" (Bangkok Post, June 30,2006$){ }^{7}$ This speech was given "amid rumors of a possible coup" (The Nation, June 30, 2006). The Nation (July 2, 2006) stated, "Public speculation was that Thaksin was taking on Privy Council president Gen. Prem Tinsulanonda with a direct challenge for a head-to-head power play."

The public did not have to wait long for a reaction from Prem. On July 14, 2006, he donned his cavalry uniform and delivered a speech to 950 cadets at the Chulalomklao Royal Military Academy -in the presence of former army commanders Chavalit Yongchaiyudh and Surayud Chulanont (a fellow member of the Privy Council who had many conflicts with Thaksin when he was at the helm of the army), and current Army Commander-in-Chief Sonthi Boonyaratglin. Prem's core point was that the military belonged to the King and the nation, not to any particular government. Famously, he likened the respective prime ministers to mere "jockeys," while the owner was somebody else. He urged the cadets to embrace professionalism-which in this context does not mean keeping the military out of politics, but being loyal to the King and the country's long-term goals, if necessary against a "jockey" who is on the wrong track.

Shortly afterwards, Army Commander Sonthi deprived Thaksin's classmates from the Armed Forces Academy's Preparatory Class 10 of much of their operational military power by transferring many of their trusted middle-ranking officers to other positions. A commentator in the Bangkok Post (July 21, 2006) had this to say: "The latest military reshuffle serves as an unmistaken

\footnotetext{
${ }^{7}$ In order to defend himself against the public protests, and perhaps a coup, Thaksin had started to use democracy rhetoric heavily. Since the establishment of TRT up to the time of the protests, he had hardly ever even mentioned the word democracy. Apparently in reaction to suspicions of his disloyalty to the King, Thaksin started to wear yellow polo shirts.
} 
message to Mr. Thaksin and his ex-classmates at the pre-cadet school that Gen. Sonthi's first and foremost loyalty is not to them." Prem continued to drum up support for his views of the role of the military vis-à-vis the political leaders. On July 28, he gave a special lecture to 350 cadets at the Naval Academy, stressing that national leaders must be ethical and have a high degree of morality:

Only good people have ethics and morals. Bad people don't. People who work in public office or those who are commanders and leaders, in particular, must embrace ethics and morality otherwise things will collapse. There will be corruption, favoritism, nepotism and greed if leaders lack ethics and morals. Individuals who have no ethics and morals are bad people who are full of greed. They may want to live comfortably with a lot of money. But if they have acquired wealth through illegal or unethical means, they no longer deserve to be in this country (Bangkok Post, July 29, 2006). ${ }^{8}$

Prem's final stop on his tour was the Air Force Academy. On August 31, 2006, he concluded his lecture with the ominous remark that "The nation is sacred. People who think about using it for personal benefit or group benefits will be met with misfortune. Phra Sayam Thewathirat [Thailand's guardian spirit] always protects good people and condemns bad people to a life of suffering" (Bangkok Post, Sep. 1, 2006). Moreover, Prem referred to a famous piece of royal advice, originally given in 1969, that has often been quoted in Thailand:

There are both good and bad people in our country. No one can make everyone a good person. Keeping the country in peace and order is not about making everyone good, but about having good people govern and preventing bad people from rising to power and causing trouble (ibid.).

Not even three weeks later, the coup d'état of September 19, 2006, aimed at doing just this-"preventing bad people from rising to power and causing trouble." 9 Given the events described above, it is not surprising that Prem would be seen as a major driving force

\footnotetext{
8 TRT's deputy spokesman felt the need to defend Thaksin against Prem's remarks, saying, "I don't know who Gen. Prem referred to as an unethical leader in his lecture. But Mr. Thaksin has proved that he is ethical and loyal to the institution [of monarchy] and people can make their own judgment who is ethical or not" (Bangkok Post, July 29, 2006).

${ }^{9}$ Pro-Thaksin groups certainly see this in a different light. About a month after the coup, a cartoon book describing Thaksin's life story appeared in bookshops. Its stated aim was to make young people understand all the good deeds Thaksin had done for the people before he was unjustly toppled by the military. The text of the last picture reads, "Father thinks that this hero of the poor will for sure not abandon the poor! Thus, father believes that he will return" (Posatorn 2006: 192).
} 
behind the coup. ${ }^{10}$ Three days after the coup I went for a haircut. My usual barber was polite, but he repeatedly expressed his strong disagreement with the coup and Prem's assumed role. The president of the King's Privy Council, he stressed, should have remained neutral. Four weeks after the coup, I had a long talk with a taxi driver on my way home from the Mo Chit BTS station. At times very emotionally, he expressed views similar to those of my barber. When we passed the big billboard in front of Chatuchak Park showing Prem warning against the dangers of drug abuse, he pointed at the billboard and exclaimed, "This guy should have stayed out of that," an opinion he repeated a few times during our ride. ${ }^{11}$

Thongchai Winichakul, a veteran of the student movement in the 1970s and now a professor of history at the University of Wisconsin, put it this way, "This coup is not only for toppling Thaksin. It is a royalist coup with a purpose. If one is not so naïve, Prem's fingerprints and footprints are all over the place for us to see" (Thongchai 2006a: 6). According to Thongchai (ibid.), the purpose of the coup-abstracting somewhat from the detailed conditions leading to the event-was to make sure that "a government that is obedient, even submissive, to royalist leadership" is in place in case of succession. In a subsequent Thailanguage article, headlined with the English words "The Kingmakers" (Thongchai 2006b), the author expanded on the historical role which members of the royal family (chao nai) and the nobles and bureaucrats (khunnang) had in managing the successions from one Thai king to another throughout history. Thongchai's closing paragraph reads:

The closer the time of the important change comes, these highly respected senior people must do everything in order to be sure that this important change will occur under conditions that they can control. They cannot let anybody with a lot of power go against their will (ibid.).

Although the preceding paragraph is followed by the sentence "But all this is entirely about the past," the potential contemporary meaning is all too obvious. ${ }^{12}$ In any case, readers will have to keep

10 Sonthi Limthongkul's Phuchatkan (Manager) newspaper (Oct. 14-15, 2006) printed a cartoon on its front page showing Thaksin, with a badly bruised face, obviously in great pain. The balloon representing Thaksin's thoughts shows Prem with a mischievous grin, holding up his right hand wearing a boxing glove, saying "Does it hurt, son?"

${ }^{11}$ When I cautioned the driver somewhat, since he expressed his opinions directly and strongly, he joked that, in his taxi, we were amongst ourselves, and we had no tape recorder. He said that he did not mind Thailand having a king, but he wanted him to be under the constitution, and to keep out of politics.

12 Duncan McCargo (2005) argued against a king-centered account of the Thai monarchy. He suggested visualizing the king at the center of a network, called 
in mind that the Thai royal-military-bureaucratic culture dealt with here does not normally submit to demands for democratic accountability and transparency, nor for academic scrutiny. ${ }^{13}$ For this reason, we might never know what "really" were all the reasons behind the coup.

\section{Major coup announcements}

The first obvious sign that a coup was underway was when TV Channel 5 replaced its usual program with clips showing the Kingwhile playing patriotic music. The other channels continued their normal programs for a while, until they also switched to royal programs. On Channel 9, Thaksin was able to read-from New York -his state-of-emergency announcement: the announcement of transferring Army Commander Gen. Sonthi to the Prime Minister's Office, and most of his announcement appointing Supreme Commander Gen. Ruengroj Mahasaranong to take care of the situation in Bangkok. At around 23.00 hours, white text on blue background appeared on all channels:
At the moment, the Council for the Reform of the Democratic System of Government with the King as Head of State, which is composed of the Commanders-in-Chief of the armed forces and the Commissioner-General of the Royal Police, has successfully taken control over Bangkok and its vicinity without meeting any resistance. So as to maintain peace and order in the nation, the Council seeks the cooperation of the

\footnotetext{
"network monarchy." From this perspective, Prem and other important royalists are seen as mere "proxies," who act on behalf of the King. Thongchai's approach, on the other hand, posits the existence of an independent monarchist or royalist model of the polity, including corresponding networks of people. From this perspective, concrete kings are seen as office holders with very different impacts on the status of the monarchy as an institution. And they are evaluated from this perspective; a typical academic example is Kobkua (2003). If Thais operating within this model criticize a past monarch, or a possible successor, they do not do it in order to run the monarchy down. On the contrary, their aim is to protect the monarchy and preserve its future significance. Besides, people such as Prem Tinsulanonda, Prawase Wasi or Anand Panyarachun, who McCargo sees as members of the "network monarchy," can also be perceived as embodiments of elite military, technocratic, and bureaucratic worldviews, including respective self-interests.

13 A telling example of this lack of democratic liberalism is the answer Prem recently gave on Colum Murphy's concluding interview question. Murphy asked him, "On the issue of the book The King Never Smiles, by Paul Handley, isn't the type of discussion that the book can promote-namely open debate on the role of the monarchy-good for Thailand? General Prem: I don't like it. The nation doesn't like it. It's a hearsay book and is not based on the fact. We are worried [about] the foreigners who read it. My suggestion is-please ignore that book. It's useless" (http://www.feer.com). Meanwhile, the book has been making its rounds in Thailand amongst Thais and foreigners alike. A Thai friend of mine provided me with a photocopy, obtained from one of her Thai friends, who got the original. One was somewhat reminded of the time of the Samisdat circulars in the former Soviet Union.
} 
public to remain calm and offers its apologies for any inconvenience caused. ${ }^{14}$

Fifty minutes later, the coup group provided their justification for their seizure of power:

As it has become clearly apparent that the administration of the present caretaker government has led to severe rifts and disunity among the Thai people unprecedented before in Thai history, with different sides seeking to win using various means amidst prospects of the situation worsening with every day, the majority of the people are suspicious and untrusting of the government's administration which shows signs of rampant corruption, malfeasance, political interference in government agencies and independent organizations affecting their ability to perform their duties as prescribed by the Constitution of the Kingdom of Thailand, creating problems and obstacles for the conduct of political activities, as well as several actions verging on lèsemajesté against His Majesty the King who is highly respected by the Thai people. Although many sectors within society have continuously tried to compromise to resolve the situation, the divisions that exist could not be lessened. The Council for Democratic Reform, composed of the Commanders-in-Chief of the Armed Forces and the Royal Thai Police Commissioner-General, has therefore found it necessary to seize control of the country's administration from this moment onwards. The Council wishes to reaffirm that it does not intend to administer the country itself and will restore the democratic governmental system with a monarch as head of state to the Thai people as soon as possible so as to maintain peace and order within the Kingdom, as well as to extend the highest reverence to the monarchy, which commands the deepest respects of all the Thai people.

Announced on September 19, B.E. 2549 (2006), 2350 hours General Sonthi Boonyaratglin Leader of the Council for Democratic Reform ${ }^{15}$

From what has been said above about the King's vision of the most appropriate course of action to get out of the country's political crisis - the role of the judiciary, democracy, clean and fair elections -one might well assume that the coup in fact contradicted the

\footnotetext{
14 Except for the name of the coup group, whose official English-language name is Council for Democratic Reform, the text is the unofficial translation to be found at http://www.mfa.go.th/web/2473.php. The inclusion of the police in this announcement made many people wonder whose coup this was, since the police was thought to support Thaksin.

15

http://www.mfa.go.th/web/2473.php. These two announcements were combined in a televised address by the coup group on September 20, 2006, at about 09.00 hours.
} 
King's wishes. However, the day after the coup, he took the unusual step of royally appointing General Sonthi as the head of the coup group. The Nation (Sept. 22, 2006) reported this event, and provided an English-language translation (which has been somewhat adjusted here) of the "Announcement appointing the chairperson of the Council of Democratic Reform under Constitutional Monarchy,"16 which plainly put the blame for the coup on ousted Prime Minister Thaksin:

In a ceremony broadcast on TV pool, Army Commander in Chief Gen Sonthi Boonyaratglin stood before a shrine to HM the King while Adjutant Generals Department's Adjutant Maj Gen Manote Premwongsiri read out the Royal Order:

Gen Sonthi informed HM the King that the administration of the state by the government under Prime Minister Thaksin Shinawatra has created the problem of division within the nation and destroyed national unity as has never happened before in the country's history. Most people believe that this administration was plagued with widespread irregularities and corruption. Independent bodies were subjected to political domination resulting in political activities encountering many problems and obstacles. Though many sectors of society continuously had tried to compromise and ease the situation, they were unable to restore peace and order of the country. Therefore, the armed forces, police and civilians have seized administrative power under the leadership of General Sonthi Boonyaratglin, the head of the Council of Democratic Reform under Constitutional Monarchy. Thus, in order to create peace and order for the country, HM the King has issued the Royal Order for General Sonthi as the leader of the Council of Democratic Reform under Constitutional Monarchy. We urge the public to remain calm, and we ask that all government civil servants follow the orders of General Sonthi Boonyaratglin.

In white uniform, Sonthi-flanked by other officers-kneeled and bowed before a portrait of the King above the flower-bedecked shrine.

Given this apparent inconsistency, many observers found it necessary to ask what the involvement of the King was in this coup. Old-hand social critic Sulak Sivaraksa, currently charged with lèsemajesté for remarks on the monarchy he made in the left-leaning

\footnotetext{
16 A PDF file of the original Thai-language announcement can be found at http://www.mfa.go.th/web/2473.php. The Thai name of the coup group followed Article 2 of the Constitution abrogated by the coup, which reads, "Thailand adopts a democratic regime of government with the King as Head of the State."
} 
political journal Fa Diewkan, ${ }^{17}$ was quoted as having said, "If the king didn't give a nod, this never would have been possible" (Associated Press, Sept. 20, 2006). The coup plotters took speculation by foreigners about the King's role seriously enough to change the group's name from "Council for Democratic Reform under Constitutional Monarchy" (CDRM) to "Council for Democratic Reform" (CDR). They claimed that the previous English-language name "had led to misunderstanding and false interpretation in some countries and for some foreign media on the role of the monarchy" (The Nation, Sept. 27, 2006). Interestingly, the Thai-language name remained unchanged.

In any case, as has been described above, Prem had repeatedly been warning Thaksin since at least July 2005. Even the King himself, in his birthday speech in December 2005, remarked, "I ask you all to be careful, very careful with what you think, speak, or do. If you think it is right, go ahead and do it" (The Nation, Dec. 13, 2005). Ukrist (2006: 37) stated, "Some analysts consider this reshuffle [of October 2005] a turning point in the strategic military preparation aimed at overthrowing the Thaksin government." Finally, Lt. General Saprang Kalayanamit-an important actor in the coup operations-afterwards stated that preparations for the coup had been going on for seven to eight months already. "We did not start thinking about it just one or two days earlier" (Khom Chat Luek, coup special, p. 3). ${ }^{18}$ Thus, a high-level discourse on a number of political options, including a coup, had preceded the actual event. Usually, His Majesty is quite well-informed about what happens in his kingdom.

\section{Conclusion}

Three weeks after the coup, Prem Tinsulanonda added to his previous comments by saying:

The country is sacred. Whoever thinks only to take the country's interests into their own possession or for their own groups - will end in their own downfall. Phra Sayam Thewathirat [the guardian spirit] always protects the country and curses those who are evil to suffer for the rest of their lives...Hitler and a few of his people were greedy and made people fight. Our country also has this type of people (The Nation, Oct. 5, 2006).

In the next few years, Phra Sayam Thewathirat will have his hands full trying to protect the country. The nation's revered King as well

\footnotetext{
17 Sulak is no stranger to such charges (see Streckfuss 1996). The editor of the journal was also charged.

18 What immediately triggered the coup might then have been the impending military reshuffle that Thaksin might have used to deprive the military forces opposed to him of their coup-making capacity.
} 
as Prem-who have been extremely important in steering the country's course during the past decades-are close to the end of being able to play active roles. ${ }^{19}$ Nobody knows who will be able to fill the ensuing vacuum.

The new constitution being drafted might not be of much help in stabilizing the polity. The 1997 Constitution introduced party-list members of parliament with the aim of recruiting capable professionals into the policy-making process. This did not work out. The elected Senate as an apolitical assembly of wise elders also failed. The independent bodies designed to hold politicians accountable easily fell victim to socio-political intervention. What could have passed as a positive achievement-the creation of a strong prime minister who could steer the country's course independently of parliament, his political party, and his coalition partners-also turned negative. Strong the leader was indeed-too strong.

As for the political personnel, a columnist in Matichon (Oct. 26, 2006: 2) expressed an uneasy feeling, asking "What [will come] after Surayud?" He anticipated that the next election will return exactly the same politicians as before the coup to parliament and government-perhaps minus Thaksin. The coup will thus not result in a different political cast. Nor will it make voters in the countryside more similar to their fellow Thais constituting the Bangkok middle class-and it will not lead this middle class to like the electoral decisions of countryside voters more. ${ }^{20}$ The Thai polity will remain a terrain contested by a multiplicity of forces, amongst them the royalist, military, and bureaucratic elite of Bangkok, the capital's middle class, the so-called "people's sector," the rural population, and the politicians. It is this diversity, plus the impending change of vitally important actors, that makes it difficult to predict Thailand's political future.

\footnotetext{
19 Integrating forces of lesser importance, such as Prawase Wasi and Anand Panyarachun, are also of advanced age.

20 For a brief article on the democracy implications of this coup, see Nelson (2006b).
} 


\section{References}

Bidhya Bowornwathana. 2004. “Thaksin's Model of Government Reform: Prime Ministerialisation through 'A Country Is My Company' Approach." Asian Journal of Political Science

Kasian Tejapira. 2006. “Toppling Thaksin.” New Left Review 39, May-June, pp. 5-37.

Kobkua Suwannathat-Pian. 2003. Kings, Country and Constitutions Thailand's Political Development 1932-2000. London and New York: RoutledgeCurzon.

McCargo, Duncan. 1997. Chamlong Srimuang and the New Thai Politics. New York: St. Martin’s Press.

McCargo, Duncan. 2005. "Network Monarchy and Legitimacy Crisis in Thailand." The Pacific Review 18 (4): 499-519.

McCargo, Duncan, and Ukrist Pathmanand. 2005. The Thaksinization of Thailand Copenhagen: NIAS Press.

Murphy, Colum. 2006. “Thaksin, Get Out!': Why Thais Are Angry.” Far Eastern Economic Review, April, pp. 7-13.

Nelson, Michael H. 2005. "Thailand and Thaksin Shinawatra: From Election Triumph to Political Decline." eastasia.at Vol. 4, No. 2, December.

Nelson, Michael H. 2006a. "Political Turmoil in Thailand: Thaksin, Protests, Elections, and the King." eastasia.at Vol. 5, No. 1, September.

Nelson, Michael H. 2006b. "Bangkok's Elitist Coup.” Far Eastern Economic Review, October, Vol. 169, No. 8, pp. 27-30.

Pasuk Phongpaichit and Chris Baker. 2004. Thaksin: The Business of Politics in Thailand Chiang Mai: Silkworm.

Posatorn Butr-anan. 2006. Chiwit Thaksin. [The Life of Thaksin]. Bangkok: Tri O Promotion.

Streckfuss, David, ed. 1996. Modern Thai Monarchy and Cultural Politics: The Acquittal of Sulak Sivaraksa on the Charge of lese majeste in Siam 1995 and Its Consequences. Bangkok: Santi Pracha Dhamma Institute.

Thongchai Winichakul. 2002. "Remembering/Silencing the Traumatic Past: The Ambivalence Narratives of the October 1976 
Massacre in Bangkok." In Cultural Crisis and Social Memory: Modernity and Identity in Thailand and Laos, ed. by Shigeharu Tanabe and Charles F. Keyes, pp. 243-283. London: RoutledgeCurzon.

Thongchai Winichakul. 2006a. "Bad Excuse for the Coup." Available at http://rspas.anu.rdu.au/rmap/newmandala.

Thongchai Winichakul. 2006b. “'The Kingmakers.' " Krungthep Thurakit, October 18, 2006: 13.

Ukrist Pathmanand. 2006. "How Long Before the Junta Splinters?" Far Eastern Economic Review, October, Vol. 169, No. 8, pp. 36-38.

Yos Santasombat. 1989. "The End of Premocracy in Thailand." In Southeast Asian Affairs 1989, pp. 317-335. Singapore: ISEAS.

Michael Nelson is a visiting scholar at the Faculty of Political Science, Chulalongkorn University, Bangkok, Thailand and a senior researcher at the Institute of Southeast Asian Studies, University of Passau, Germany. 